\title{
The Effect of Insulin Antibodies on Glucose Uptake by the Isolated Rat Diaphragm
}

\author{
By P. H. WRIGHT \\ Department of Chemical Pathology, Guy's Hospital Medical School, London, S.E. 1
}

(Received 30 October 1958)

During insulin therapy generalized allergic reactions are sometimes observed in diabetic subjects and disappear in many cases when the insulin preparation is changed (see Joslin, Root, White \& Marble, 1952). These allergic manifestations are often the result of sensitization to impurities in the insulin preparations (Jorpes, 1949). It is also known, however, that insulin itself is antigenic and that antibodies appear in the plasma of human subjects (Berson, Yalow, Bauman, Rothschild \& Newerly, 1956) and of animals (Moloney \& Coval, 1955) after only short courses of insulin therapy; no such antibodies are demonstrable in human or animal subjects who have not received parenteral insulin therapy. Serum from insulin-treated human subjects and animals (i) neutralizes the convulsive effect of insulin in mice (Banting, Franks \& Cairns, 1938; Lowell, 1942; Sehon, Kaye, McGarry \& Rose, 1955; Moloney \& Coval, 1955); (ii) binds added 131I-labelled insulin in the $\gamma$-globulin (Burrows, Peters \& Lowell, 1957) or between the $\beta$ - and $\gamma$ globulin (Berson \& Yalow, 1957) fractions of the plasma proteins; (iii) agglutinates or haemolyses red cells conjugated with insulin (Arquilla \& Stavitsky, 1956a).

In the present investigations serum from guinea pigs sensitized to purified bovine insulin by the method described by Moloney \& Coval (1955) was examined to determine its ability to inhibit the effects of insulin and other hypoglycaemic agents upon the isolated rat diaphragm.

\section{MATERIALS AND METHODS}

Insulin. Insulin samples from four sources were used (potency stated in international units): (a) bovine, six times recrystallized $(22 \cdot 2 \mathrm{units} / \mathrm{mg}$.); (b) pig, recrystallized once (approx. 20 units/mg.); (c) sheep, recrystallized once (approx. 20 units/mg.); (d) human, crude (approx. 1 unit/ mg.); this specimen was extracted from human pancreases removed at autopsy $12-15 \mathrm{hr}$. after death. No gross evidence of disease was visible in these glands, which were removed from subjects who had not suffered from diabetes.

Antigen. Recrystallized bovine insulin (10 mg.) was dissolved in $10 \mathrm{ml}$. of aq. $0.6 \%$ phenol acidified with hydrochloric acid to $\mathrm{pH} \mathbf{2 \cdot 6}$ (approx.) and emulsified in a Waring Blendor with a mixture of $7 \mathrm{ml}$. of liquid paraffin (B.P.) and $3 \mathrm{ml}$. of lanolin (Adeps Lanae, anhydrous, B.P.).
Sensitization of guinea pigs. Each guinea pig, of either sex, was injected subcutaneously with $2 \mathrm{ml}$. of freshly prepared antigen, $1 \mathrm{ml}$. being injected between the shoulders and $0.5 \mathrm{ml}$. into the inner aspect of each thigh. The same dose of antigen was injected 1 month later, the animal being bled by cardiac puncture 2 weeks after the second injection. Subsequent specimens of serum were in some cases obtained from these animals 2 weeks after a further similar course of antigen injections. Groups of four animals were sensitized simultaneously, the serum from animals in each group being combined and stored at $-10^{\circ}$ until required. Serum obtained from guinea pigs after sensitization to bovine insulin by this method is here termed insulin antiserum.

Hypoglycaemic agents. The actions of some synthetic hypoglycaemic agents upon glucose uptake of the isolated rat diaphragm were also studied; these included $n$-decamethylene-1:10-diguanide (Synthalin, L. Light and Co. Ltd., Bucks), $N^{\prime}$-phenylethyl diguanide (phenethyl diguanide), $\quad N$-(n-butyl)- $N^{\prime}$-( $p$-aminophenyl)-sulphonyl urea (carbutamide) and $N$-( $n$-butyl $)-N^{\prime}-(p$-methylphenyl)-sulphonyl urea (tolbutamide).

Glucose consumption of isolated rat hemi-diaphrams. The experimental procedure used in estimation of glucose uptake by rat hemi-diaphragms has been described in detail elsewhere (Wright, 1957). Wistar rats (120-140 g.), bred in Guy's Hospital Medical School from a strain supplied by the Chester Beatty Research Institute, were fasted for $24 \mathrm{hr}$., weighed and killed by decapitation. The diaphragms were removed, soaked in Krebs-Ringer bicarbonate buffer (Umbreit, Burris \& Stauffer, 1945) at $0-8^{\circ}$ for $15 \mathrm{~min}$. The hemi-diaphragms were dissected, blotted on filter paper and then placed in Warburg flasks containing $2 \mathrm{ml}$. of incubation medium; in no experiment were the hemidiaphragms from any one rat incubated in the same medium. After being gassed for $5 \mathrm{~min}$. with $\mathrm{O}_{2}+\mathrm{CO}_{2}$ (95:5), the flasks were incubated at $37^{\circ}$ for $90 \mathrm{~min}$. with continuous agitation (120 oscillations $/ \mathrm{min}$.; $4 \mathrm{~cm}$. amplitude). The glucose concentration in each medium was determined before incubation and in each flask after incubation; a slight modification of King's method of glucose estimation was used (see Wright, 1957). On removal from the flasks the hemi-diaphragms were washed in water, blotted and weighed after drying in air at $120^{\circ}$ for $2 \mathrm{hr}$. Glucose uptake of each individual hemi-diaphragm is expressed as $\mu \mathrm{g}$. of glucose $/ 10 \mathrm{mg}$. dry wt. of muscle/ $90 \mathrm{~min}$. incubation.

Incubation media. The hemi-diaphragms were incubated in Krebs-Ringer bicarbonate buffer (Umbreit, Burris \& Stauffer, 1945) containing glucose in a concentration of $280-300 \mathrm{mg} . / 100 \mathrm{ml}$. This medium is termed 'saline buffer'. Insulin was incorporated by serial dilution of stock insulin solutions (usually 50 units $/ \mathrm{ml}$. in aq. $0.6 \%$ acetic 
acid) with saline buffer immediately before each experiment. Guinea-pig or rabbit serum was added to the incubation medium after the addition of insulin or other hypoglycaemic agent and $1-1 \frac{1}{2} \mathrm{hr}$. before exposure to the tissue.

\section{RESULTS}

The glucose uptake of hemi-diaphragms incubated in saline buffer alone (basal uptake) was unaffected by the addition of serum from normal guinea pigs or of that from guinea pigs sensitized to bovine insulin (insulin antiserum) (Table 1). The uptake of muscle incubated in saline buffer containing insulin (1 m-unit/ml.) was also unaffected when normal guinea-pig serum was added, but was reduced when insulin antiserum was present (Table 2). The inhibitory effect of the insulin antiserum upon the action of bovine insulin appeared to depend upon the concentration of antiserum present. All five samples of insulin antiserum obtained at various times from three groups of guinea pigs (A, B and C) abolished the stimulant action of the standard concentration of insulin used (1 m-unit $/ \mathrm{ml}$.) provided that they were present in concentrations equal to or greater than $0.02 \mathrm{ml}$. of serum $/ \mathrm{ml}$. of incubation medium. It was also noted that serum drawn from guinea pigs 5 months after the last injection of antigen showed no inhibitory effect, though the inhibition returned after the next course of antigen injections. Specimens of antiserum stored at $-10^{\circ}$ for 6 months showed no loss of inhibitory activity.

Insulin antiserum from one group of guinea pigs sensitized to bovine insulin also inhibited the stimulant effects produced by comparable concentrations of human, pig and sheep insulin. The stimulant effect of bovine insulin labelled with ${ }^{131} \mathrm{I}$, like that of the recrystallized insulin from which it was produced, was also reduced (Table 3 ).

By contrast the stimulant effects of Synthalin and phenethyl diguanide (Table 4) were not reduced by the addition of insulin antiserum in a concentration known to be effective against bovine insulin. Carbutamide and tolbutamide are without stimulant action. The effects produced by these hypoglycaemic agents confirm the majority of findings previously reported (see Lundbaek, Nielson \& Rafaelson, 1958).

A specimen of serum obtained from rabbits sensitized against bovine insulin and known to agglutinate insulin-sensitized red cells (titre 1/300) was kindly provided by $\operatorname{Dr} A$. B. Stavitsky. When tested in the same way as the guinea-pig antiserum it produced no inhibitory effect even when present in high concentration $(0.1 \mathrm{ml}$. of serum $/ \mathrm{ml}$. of incubation medium). It was thought possible that the action of this serum might depend upon the presence of complement which had been removed during heat-treatment of the serum. When fresh normal rabbit serum was also added, however, no inhibitory effect was observed (Table 5).

The insulin antiserum obtained from guinea pigs was fractionated by treatment with $19 \%$ sodium sulphate, and the globulin fraction, after dialysis, was found to possess the inhibitory activity. It was also shown that antiserum when added to bovine insulin before injection produced the protective effect described by Moloney \& Coval (1955). Injection of bovine insulin (15 units) by the intracardiac route into sensitized guinea pigs produced typical symptoms of severe fatal anaphylaxis within 5 min., whereas only hypoglycaemic symptoms developed in normal guinea pigs in $2-3 \mathrm{hr}$.; none of the latter animals died.

Table 1. Effect of serum from normal and insulin-sensitized guinea pigs upon glucose uptake of the isolated rat hemi-diaphragm

For details of the saline buffer see Materials and Methods.

\begin{tabular}{|c|c|c|c|c|}
\hline \multicolumn{3}{|c|}{ Guinea-pig serum } & Uptak & lucose* \\
\hline Туре & Batch & $\begin{array}{c}\text { (ml./ml. of } \\
\text { incubation } \\
\text { medium) }\end{array}$ & $\begin{array}{l}\text { Saline buffer } \\
\text { alone (basal) }\end{array}$ & $\begin{array}{c}\text { Saline } \\
\text { buffer + serum }\end{array}$ \\
\hline Normal & - & 0.1 & $\begin{array}{c}266 \pm 11 \cdot 3 \\
(7)\end{array}$ & $\begin{array}{c}280 \pm 16 \cdot 9 \\
(7)\end{array}$ \\
\hline Anti-insulin & $\begin{array}{l}\mathbf{A}_{2} \\
\mathrm{~B}_{2}\end{array}$ & 0.03 & $\begin{array}{c}279_{ \pm}+14 \cdot 1 \\
(6)\end{array}$ & $\left\{\begin{array}{c}264 \pm 10 \cdot 3 \\
(5) \\
264 \underset{ \pm 15 \cdot 2}{(4)}\end{array}\right.$ \\
\hline
\end{tabular}

* Uptake of glucose ( $\mu$ g. of glucose/10 mg. dry wt./90 min. \pm s.w.M.) of isolated hemi-diaphragms incubated in saline buffer alone or in buffer containing added guinea-pig serum; the number of hemi-diaphragms incubated is given in parenthesis. 
Vol. 7I

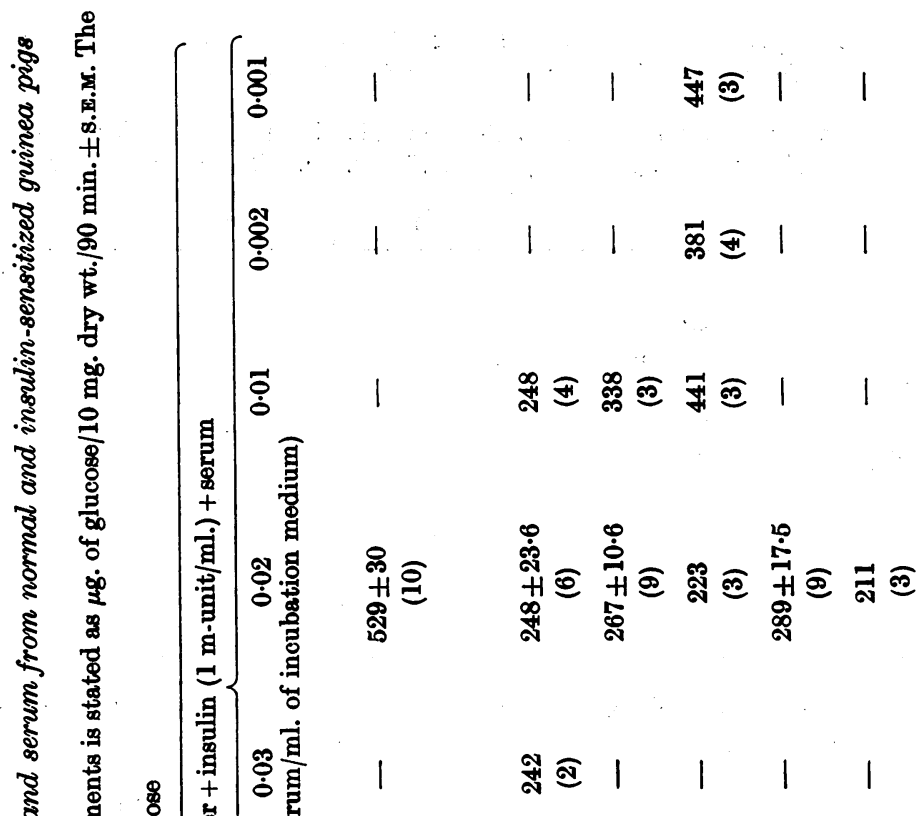

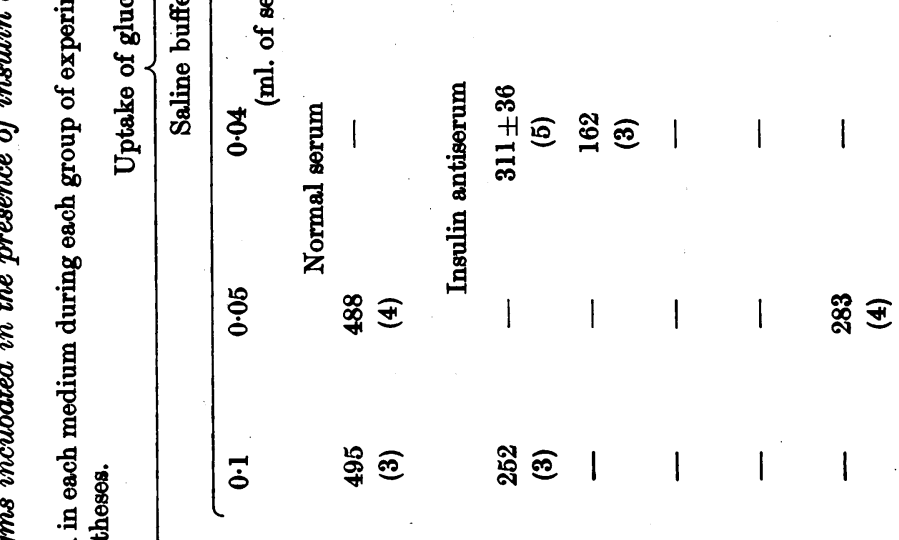

है

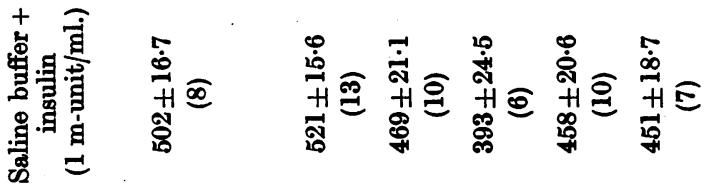

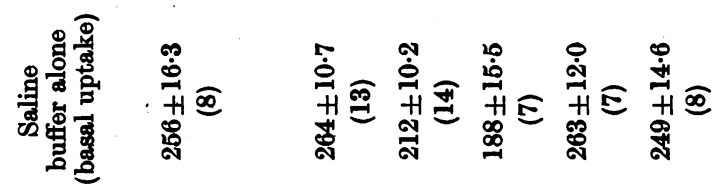
完宁离 ๓

$\pi$ m a n

ง

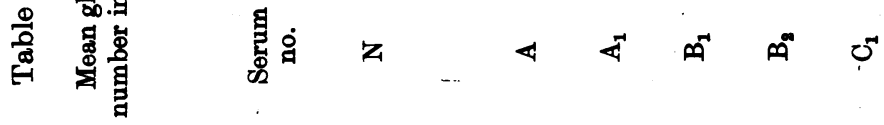


Table 3. Effect of serum from guinea pigs sensitized to bovine insulin upon the actions of insulin from various animal sources upon the isolated rat hemi-diaphragm

In each experiment four hemi-diaphragms were incubated individually in each medium, the mean glucose uptake in each case being stated as $\mu \mathrm{g}$. of glucose/ $10 \mathrm{mg}$. dry wt./90 min.; the S.D. in all cases was 30-50.

\begin{tabular}{|c|c|c|c|c|}
\hline \multirow[b]{3}{*}{$\begin{array}{l}\text { Source of } \\
\text { insulin }\end{array}$} & \multicolumn{4}{|c|}{ Uptake of glucose } \\
\hline & \multirow[b]{2}{*}{$\begin{array}{c}\text { Saline } \\
\text { buffer alone } \\
\text { (basal uptake) }\end{array}$} & \multirow[b]{2}{*}{$\begin{array}{c}\text { Saline } \\
\text { buffer }+ \\
\text { insulin* }\end{array}$} & \multicolumn{2}{|c|}{ Saline buffer + insulin $*$ + antiserum } \\
\hline & & & $\begin{array}{c}0.05 \\
\text { ml. of antiserum/ } \\
\text { ml. of medium }\end{array}$ & $\begin{array}{c}0.02 \\
\text { ml. of antiserum/ } \\
\text { ml. of medium }\end{array}$ \\
\hline $\begin{array}{c}\text { Bovine } \\
\text { Bovine } \\
\text { (131I-labelled) }\end{array}$ & $\stackrel{266}{-}$ & $\begin{array}{l}470 \\
388\end{array}$ & $\begin{array}{l}283 \\
284\end{array}$ & $\stackrel{288}{-}$ \\
\hline Human & 285 & 493 & 254 & 307 \\
\hline Pig & 284 & 485 & 314 & 320 \\
\hline Sheep & 259 & 459 & 256 & 315 \\
\hline
\end{tabular}

Table 4. Glucose uptake of rat hemi-diaphragms incubated in the presence of synthetic hypoglycaemic agents and insulin antiserum

Hemi-diaphragms were incubated in saline buffer in the presence of the hypoglycaemic agent and, with active agents, insulin antiserum (concentration $0.05 \mathrm{ml}$. of serum $/ \mathrm{ml}$. of incubation medium). Uptake of glucose of hemi-diaphragms incubated in each medium (number given in parentheses) is given as $\mu \mathrm{g}$. of glucose/10 mg. dry wt./90 min. \pm s.r.M.

\begin{tabular}{|c|c|c|c|c|}
\hline \multirow[b]{2}{*}{$\begin{array}{c}\text { Hypoglycaemic } \\
\text { agent }\end{array}$} & \multirow[b]{2}{*}{$\begin{array}{l}\text { Concn. of } \\
\text { agent } \\
\text { (mg./100 ml.) }\end{array}$} & \multicolumn{3}{|c|}{ Uptake of glucose } \\
\hline & & $\begin{array}{c}\text { Saline buffer } \\
\text { alone }\end{array}$ & $\begin{array}{c}\text { Saline buffer }+ \\
\text { agent }\end{array}$ & $\begin{array}{c}\text { Saline buffer + } \\
\text { agent }+ \\
\text { antiserum }\end{array}$ \\
\hline Carbutamide & 50 & $\underset{(8)}{263 \pm 6}$ & $\underset{(8)}{244 \pm 19}$ & - \\
\hline Tolbutamide & 50 & $289_{(8)}^{ \pm 12}$ & $274 \underset{(8)}{ \pm} 23$ & - \\
\hline Synthalin & 5 & $\underset{(5)}{231_{ \pm}}$ & $\underset{(5)}{339_{ \pm}^{ \pm 21 \cdot 4}}$ & $\begin{array}{c}444 \pm 8 \cdot 0 \\
(6)\end{array}$ \\
\hline $\begin{array}{c}\text { Phenethyl } \\
\text { diguanide }\end{array}$ & 50 & $261_{(5)}^{ \pm} 20 \cdot 1$ & $\mathbf{3 7 4}_{(5)}^{ \pm}$ & $\underset{(6)}{441 \pm 21}$ \\
\hline
\end{tabular}

Table 5. Effect of serum from insulin-sensitized rabbits upon the action of bovine insulin on the isolated rat hemi-diaphragm

Hemi-diaphragms were incubated individually in saline buffer with or without addition of insulin (1 m-unit/ml.), normal rabbit serum $(0.05 \mathrm{ml}$. of serum $/ \mathrm{ml}$. of medium) or serum from insulin-sensitized rabbits. The mean glucose uptake of hemi-diaphragms incubated in each medium (number shown in parentheses) is stated as $\mu \mathrm{g}$. of glucose/10 mg. dry wt./90 min.; the s.D. in each case was 30-50. When added alone, insulin antiserum was added in concentrations of 0.1 , 0.05 and $0.02 \mathrm{ml}$. of serum $/ \mathrm{ml}$. of medium, but when added with normal serum its concentration was $0.05 \mathrm{ml}$. of serum/ml. of medium.

Uptake of glucose

\begin{tabular}{|c|c|c|c|c|c|c|}
\hline \multirow[b]{2}{*}{$\begin{array}{l}\text { Saline } \\
\text { buffer } \\
\text { alone }\end{array}$} & \multirow[b]{2}{*}{$\begin{array}{c}\text { Saline } \\
\text { buffer }+ \\
\text { insulin }\end{array}$} & \multirow[b]{2}{*}{$\begin{array}{c}\text { Saline } \\
\text { buffer }+ \\
\text { insulin }+ \\
\text { normal serum }\end{array}$} & \multirow{2}{*}{$\begin{array}{c}\text { Saline } \\
\text { buffer }+ \\
\text { insulin }+ \\
\text { normal serum }+ \\
\text { insulin } \\
\text { antiserum }\end{array}$} & \multicolumn{3}{|c|}{ Saline buffer + insulin + antiserum } \\
\hline & & & & $\begin{array}{c}0 \cdot 1 \\
\text { ml. of } \\
\text { antiserum/ml. } \\
\text { of medium }\end{array}$ & $\begin{array}{c}0.05 \\
\text { ml. of } \\
\text { antiserum/ml. } \\
\text { of medium }\end{array}$ & $\begin{array}{c}0.02 \\
\text { ml. of } \\
\text { antiserum } / \mathrm{ml} . \\
\text { of medium }\end{array}$ \\
\hline $\begin{array}{c}250 \\
(4)\end{array}$ & - & $\begin{array}{c}476 \\
(4)\end{array}$ & $\begin{array}{c}476 \\
(4)\end{array}$ & - & $\begin{array}{c}456 \\
(4)\end{array}$ & - \\
\hline $\begin{array}{c}199 \\
(2)\end{array}$ & $\begin{array}{c}431 \\
\text { (3) }\end{array}$ & - & - & $\begin{array}{c}455 \\
\text { (3) }\end{array}$ & - & $\begin{array}{c}440 \\
(4)\end{array}$ \\
\hline
\end{tabular}




\section{DISCUSSION}

These results demonstrate that serum from guinea pigs sensitized to bovine insulin will inhibit an effect produced by insulin in vitro. This inhibition does not appear to be species-specific, since serum from guinea pigs sensitized to insulin extracted from the pancreas of one animal (ox) abolishes the stimulant effect of insulin extracted from the pancreases of others (sheep, pigs and human beings). It is specific for insulin only in so far as it does not abolish the stimulant effects of the synthetic hypoglycaemic agents tested.

Moloney \& Coval (1955) showed that such insulin antiserum neutralizes the hypoglycaemic effect of insulin in vivo, and that this neutralizing effect was not species-specific. They concluded that it was due to the presence in the guineapig serum of insulin antibodies. Since then P. J. Moloney (personal communication, 1958) has demonstrated that such serum will precipitate insulin in vitro and that the precipitate has the properties of an antigen-antibody complex. Arquilla \& Stavitsky (1956a) showed that serum obtained from rabbits after prolonged treatment with intravenous alum-precipitated insulin will agglutinate red cells conjugated with insulin; this effect is abolished if the serum is first incubated in the presence of insulin. They concluded $(1956 b)$ that this effect is due to the presence in the serum of antibodies which are specific but not speciesspecific for insulin. The neutralizing effect of serum from insulin-treated animals and human beings has been demonstrated in many laboratories (vide supra) and it has been shown that the active component of the serum is a $\gamma$-globulin (Sehon et al. 1955). However, serum obtained from insulinsensitized rabbits and known to agglutinate insulin-conjugated red cells did not inhibit the action of bovine insulin upon the isolated rat diaphragm either in the presence or the absence of normal rabbit serum (Table 5). This failure could be due to the low titre of the antiserum (1/300), to loss of activity during transit by post or to the long interval between the exposure of the serum to insulin and subsequent introduction of the isolated muscle $(60-90 \mathrm{~min}$.). On the other hand, rabbits are extremely resistant to the sensitizing effects of insulin (see Moloney \& Goldsmith, 1957) and the protective effect of serum obtained from insulin-sensitized rabbits is much less pronounced than that of serum from sensitized guinea pigs. It is possible therefore that the antibodies which inhibit the physiological effects of insulin upon the intact animal or isolated muscle are not identical with those which react with insulin-conjugated red cells.

With the present technique it is possible to abolish the stimulant effects of small amounts of insulin which are insufficient to produce significant effects on injection into mice. It can therefore be used to aid in the identification of small amounts of biologically active material in tissues or tissue extracts. Thus fractions of bovine-plasma proteins (Taylor, 1959; Wright, 1959) and extracts of tissue from a woman murdered by injections of insulin (Birkinshaw et al. 1958) were found to stimulate glucose consumption of the isolated rat diaphragm and this stimulant effect was abolished after treatment with insulin antiserum. In each case the active component had other properties which were identical with those of the pure hormone; it was destroyed by pepsin and cysteine and the biological response was qualitatively the same.

Moloney \& Coval (1955) pointed out that such antiserum does not always neutralize the effect of insulin in vivo. Thus the animal undergoing sensitization is normoglycaemic; the antibodies produced do not neutralize the insulin secreted by the pancreas of the sensitized animal. A sheep which was sensitized to pig insulin was resistant to the hypoglycaemic effect of crystalline pig and sheep insulin. These results suggest that there is an immunological difference between the endogenous insulin secreted by the animal's pancreas and the crystalline, or altered, insulin extracted from it. In addition insulin extracted from the guinea-pig pancreas is not neutralized by serum from guinea pigs sensitized to bovine or sheep insulin (Moloney \& Goldsmith, 1957). Thus besides some immunological differences between endogenous and altered insulins from the same animal, there are also differences, well recognized chemically (Brown, Sanger \& Kitai, 1955; Goldsmith \& Moloney, 1957), between insulins extracted from the pancreases of different animals. It is likely therefore that insulin preparations will be obtained whose stimulant effects upon the rat diaphragm will not be abolished by insulin antiserum prepared by the methods described above. It seems reasonable to conclude, however, that if the stimulant effect of a biologically active material upon the isolated rat diaphragm is abolished by insulin antiserum, that material must contain insulin.

\section{SUMMARY}

1. Serum obtained from guinea pigs sensitized to bovine insulin inhibits the increase normally produced by bovine insulin upon the glucose uptake of isolated rat diaphragm; serum from normal guinea pigs has no such action.

2. This inhibition is not species-specific in that serum from guinea pigs sensitized to insulin from one animal source (cattle) will inhibit the effects produced by insulin obtained from others (pigs, sheep and human beings). 
3. The stimulant effects of the synthetic hypoglycaemic agents Synthalin and phenethyl diguanide are not affected by insulin antiserum.

4. The significance of these findings is discussed and it is suggested that such insulin antiserum could be used to aid in the identification of insulin in extracts from biological materials.

I wish to thank Boots Pure Drug Co. Ltd., Nottingham, for generous supplies of the insulin preparations and the phenethyl diguanide used in these experiments, and especially Mr S. S. Randall who kindly extracted the insulin from human pancreases; Dr A. B. Stavitsky of Western Reserve University, Cleveland, U.S.A., for a sample of rabbit serum; Dr R. H. W. Britton of Hoechst Pharmaceuticals Ltd., Slough, for samples of tolbutamide and carbutamide; and Dr J. D. Pearson of this Medical School for the ${ }^{181}$ I-labelled bovine insulin. I would also like to thank Professor R. H. S. Thompson for his continued encouragement and helpful advice and Miss Beryl Hartman and Mr K. G. Kilbourn for skilled technical assistance.

\section{REFERENCES}

Arquilla, E. R. \& Stavitsky, A. B. (1956a). J. clin. Invest. 35, 458.

Arquilla; E. R. \& Stavitsky, A. B. (1956b). J. clin. Invest. 35, 467.

Banting, F. G., Franks, W. R. \& Cairns, S. (1938). Amer. J. Psychiat. 85, 562.

Berson, S. A. \& Yalow, R. S. (1957). J. clin. Invest. 36, 642.
Berson, S. A., Yalow, R. S., Bauman, A., Rothschild, M. A. \& Newerly, K. (1956). J. clin. Invest. 35, 170.

Birkinshaw, V. J., Gurd, M. R., Randall, S. S., Curry, A. S., Price, D. E. \& Wright, P. H. (1958). Brit. med. J. ii, 463.

Brown, H., Sanger, F. \& Kitai, R. (1955). Biochem. J. 60. 556.

Burrows, B. A., Peters, T. \& Lowell, F. C. (1957). J. clin. Invest. 36, 393.

Goldsmith, L. \& Moloney, P. J. (1957). Biochem. J. 66, 432.

Jorpes, J. E. (1949). Acta med. scand. Suppl. 239, 313.

Joslin, E. P., Root, H. F., White, P. \& Marble, A. (1952). The Treatment of Diabetes Mellitus, 9th ed., pp. 382-392. London: Henry Kimpton.

Lowell, F. C. (1942). Proc. Soc. exp. Biol., N.Y., 50, 167. Lundbaek, K., Nielson, K. \& Rafaelson, O. J. (1958). Lancet, i, 1036.

Moloney, P. J. \& Coval, M. (1955). Biochem. J. 59, 179.

Moloney, P. J. \& Goldsmith, L. (1957). Canad. J. Biochem. Physiol. 35, 79.

Sehon, A. H., Kaye, M., McGarry, E. \& Rose, B. (1955). J. Lab. clin. Med. 45, 765.

Taylor, K. (1959). Symp. Brit. Insulin Manufacturers: The Mechanism of Action of Insulin and other Hypo. glycaemic agents. (In the Press.)

Umbreit, W. W., Burris, R. H. \& Stauffer, J. F. (1945). Manometric Techniques and Related Methods for the Study of Tissue Metabolism, p. 194. Minneapolis, U.S.A.: Burgess Publishing Co.

Wright, P. H. (1957). Lancet, ii, 621.

Wright, P. H. (1959). Proc. 3rd Int. Congr. Diab. Fed. (in the Press).

\title{
Studies in Detoxication
}

\section{GLUCURONIDE AND ETHEREAL SULPHATE FORMATION IN HENS*}

\author{
By B. C. BALDWIN, D. ROBINSON AND R. T. WILLIAMS \\ Department of Biochemistry, St Mary's Hospital Medical School, London, W. 2
}

\section{(Received 28 October 1958)}

The fate of foreign organic compounds in the domestic fowl has not been extensively investigated. Most of the earlier studies were concerned with the synthesis of ornithuric acid $\left(N^{2} N^{5}\right.$. dibenzoylornithine, first discovered by Jaffe in 1877) because the fowl appeared to differ from most other species, since it conjugated aromatic acids with ornithine rather than with glycine. Preliminary work in this Laboratory with $\left[{ }^{14} \mathrm{C}\right]$ benzoic acid suggests that ornithuric acid formation may account for nearly half of moderate doses of benzoic acid. References to other reactions of foreign compounds in hens are few, e.g. acetylation (Crowdle \& Sherwin, 1923; Shaffer \& Beiter, 1950),

\footnotetext{
* Part 77: McIsaac, Parke \& Williams (1958).
}

methylation (Hoshiai, 1909; Takahashi, 1927; Tamura, 1924), oxidation and reduction (Crowdle \& Sherwin, 1923). Sperber (1947) found that phenols injected into hens caused an increase in the excretion of ethereal sulphates and of glucuronic acid derivatives as measured by the naphtha. resorcinol reaction, but injected benzoic acid, $p$ aminobenzoic acid and chloral did not increase glucuronic acid excretion. This suggested that hens could form the ether glucuronides of phenols, but not the ester glucuronides of aromatic acids. Wu Chang \& Johnson (1957), however, claim to have detected by paper chromatography nicotinoyl glucuronide, an ester glucuronide, in the urine of chicks giving nicotinamide or nicotinic acid. In the present work we have shown, by isolation of the 